\title{
Diana Borodziuk
}

Uniwersytet w Białymstoku

E-MAIL: dianaborodziuk95@wp.pl

\section{Życie dorosłych dzieci alkoholików}

\section{STRESZCZENIE}

$\mathrm{W}$ dobie kryzysu rodziny autorka zwraca uwagę na podobieństwa pomiędzy rodziną $\mathrm{z}$ problemem alkoholowym i rodziną w kryzysie spowodowanym współczesnymi zmianami społecznymi. Doświadczenie wychowania w rodzinie z problemem alkoholowym może prowadzić do specyficznych zmian w strukturze osobowości oraz zaburzeń emocjonalnych określanych umownie syndromem DDA. Artykuł zawiera charakterystykę DDA oraz przyjmowanych przez nie strategii życiowych. Zdaniem autorki różne formy wsparcia DDA mogą być przydatne w terapii i w procesie samorozwoju osób wychowanych w rodzinach dysfunkcyjnych.

SŁOWA KLUCzOWE: rodzina dysfunkcyjna, dorosłe dzieci alkoholików, strategie życiowe, rozwój duchowy, terapia

Rodzina to podstawowa komórka społeczna, w której przebiega proces uspołeczniania, dynamiczna struktura składająca się z różnorodnych interakcji nieustannie zachodzących między jej członkami. Dzięki temu rodzina „W sposób zamierzony i niezamierzony, zracjonalizowany i spontaniczny oddziałuje na osobowość dziecka, wytycza i utrwala określony (przez siebie uznawany i preferowany) zestaw wartości, które w wyniku interioryzacji stają się dla dziecka azymutami, ukierunkowującymi jego aktywność i postępowanie przez cale życie" (Winiarski, 20oo, s. 121). W rodzinie funkcjonalnej skutkuje to udaną adaptacją społeczną. Jednakże zmiany społeczno-ekonomiczne związane z rozwojem cywilizacji technicznej powodują, że zmienia się także rodzina, która w tych warunkach nie zawsze jest w stanie spełniać funkcję wychowawczą i socjalizującą - staje się rodziną dysfunkcyjną. Według Raportu ARC Rynek i Opinia z 2017 roku 23\% osób dorosłych i 26\% dzieci korzysta z pomocy psychologicznej. Potrzeby są znacznie większe (NIK, 2017). Na przestrzeni ostatnich pięciu lat aż sześciokrotnie wzrosła liczba małoletnich, którzy odebrali sobie życie z powodu problemów szkolnych. Ogółem liczba samobójstw w grupie wiekowej 7-18 lat wzrosła dwukrotnie (Klinger i Otto, 2019). Kryzys współczesnej rodziny i związana z nim niewydolność 
wychowawcza mogą być przyczyną zaburzeń w rozwoju osobowościowym dzieci, które z tego powodu nie osiągają dojrzałości społecznej. W rodzinach wieloproblemowych często dochodzi do "dziedziczenia dysfunkcji” (Biernat, 2015). Aby zapobiec tym negatywnym zjawiskom, potrzeba wypracowania skutecznych form pomocy poszczególnym członkom rodziny przy jednoczesnym uwzględnieniu systemu rodzinnego jako całości.

Strukturę i mechanizmy rodziny dysfunkcyjnej oraz konsekwencje, z jakimi muszą się borykać w dorosłym życiu osoby w niej wychowane, doskonale obrazują badania dotyczące dorosłych dzieci alkoholików (Bradshaw, 1994; Woititz, 1992). Uważam, że w sytuacji kryzysu rodziny warto skorzystać z doświadczeń i modelu oddziaływań terapeutycznych, które potwierdziły swoją skuteczność w przypadku członków rodziny alkoholowej. Ponieważ kwestią najważniejszą wydaje się nabycie zdolności do przekraczania destrukcyjnych uwarunkowań środowiska rodzinnego, $\mathrm{w}$ poniższym artykule skupię się na doświadczeniach dorosłych osób wychowanych w rodzinach z problemem alkoholowym.

Temat dorosłych dzieci alkoholików pojawił się po raz pierwszy na przełomie XIX i XX wieku w kontekście niepełnosprawności umysłowej dorosłych osób, które wychowały się $\mathrm{w}$ rodzinie $\mathrm{z}$ problemem alkoholowym. Owa niepełnosprawność, jak pokazały późniejsze badania, była zdeterminowana przez czynniki dziedziczne ojców nadużywających alkoholu (Ślaski, 2005).

Pionierskie badania naukowe odnoszące się do dorosłych dzieci alkoholików pojawiły się dopiero w 1969 roku w książce M.R. Cork The forgotten children: A study of children with alcoholic parents. Odsłaniały one wiele problemów psychologicznych dotykających osób wychowujących się w rodzinach alkoholowych. W latach sześćdziesiątych ubiegłego wieku wykształcił się termin DDA, który jest zbliżony do dzisiejszego rozumienia tego pojęcia.

Określenie „dorosłe dzieci alkoholików” (DDA) dotyczy osób dorosłych, które wychowywały się $\mathrm{w}$ rodzinach, których codzienne życie było podporządkowane problemowi alkoholowemu jednego bądź obojga rodziców. Dorastanie w rodzinie alkoholowej pozbawiło je prawdziwego dzieciństwa oraz zmusiło do wcześniejszego wkroczenia w dorosłość. Jednakże, jako dorośli, wewnątrz wciąż są pełnymi obaw i tłumionych emocji dziećmi o nieadekwatnych wyobrażeniach własnej osoby (Kucińska, 2002). Poprzez zaabsorbowanie $\mathrm{w}$ dzieciństwie problemem alkoholowym rodziców jako dorośli mają poczucie straconego, czy wręcz odebranego dzieciństwa.

W literaturze przedmiotu szczególną uwagę zwraca się na związek terminu „dorosłe dzieci alkoholików” z istnieniem podwójnej tożsamości. Opiera się ona na byciu jednocześnie osobą dorosłą i dzieckiem, ponieważ nierozwiązane problemy z dzieciństwa i nieprzepracowane urazy stanowią 
element z przeszłości w pewien sposób determinujący funkcjonowanie w życiu dorosłym, określane mianem funkcjonowania o cechach niedojrzałości emocjonalno-społecznej (Ryś, 2007). John Bradshaw zaznacza, że „wewnątrz dorosłego dziecka alkoholików kryje się małe dziecko, które odczuwa pustkę i nienasycenie, którego potrzeby pozostają niezaspokojone, gdyż są to potrzeby dziecka ukrytego w ciele osoby dorosłej" (Bradshaw, 1994, s. 114).

Według ekspertów Państwowej Agencji Rozwiązywania Problemów Alkoholowych nie wszystkie dorosłe DDA wymagają specjalistycznego wsparcia. Eksperci wyróżniają trzy grupy osób, które tej pomocy potrzebują:

a) Podgrupa osób w aktualnym kryzysie, czyli osoby, które bez względu na fakt dorastania $\mathrm{w}$ rodzinie $\mathrm{z}$ problemem alkoholowym adaptują się i radzą sobie w życiu dorosłym, nie wykazując przejawów szczególnych trudności, problemów czy też zaburzeń. Jednakże osoby te wymagają specjalistycznej pomocy psychologicznej w sytuacjach kryzysowych.

b) Podgrupa osób z syndromem DDA, czyli osoby, które nie przejawiają głębszych zaburzeń neurotycznych, osobowościowych czy uzależnień. Problemy, które zazwyczaj je dotykają, to: trudności emocjonalne oraz trudności $\mathrm{w}$ nawiązywaniu i utrzymywaniu relacji $\mathrm{z}$ innymi ludźmi. Niekiedy mogą u nich występować pojedyncze cechy określonych zaburzeń osobowości.

c) Podgrupa źle przystosowana ze współwystępującymi zaburzeniami psychicznymi - czyli osoby, u których ujawniają się różnorodne zaburzenia, takie jak: uzależnienia, zaburzenia lękowe, zespoły symptomów nerwicowych, zaburzenia osobowości lub inne zespoły psychopatologiczne (Jabłońska, Kucińska i Schirmer, 2008).

Popularność stosowania w literaturze terminu „syndrom DDA” nie przekłada się jednak na istnienie jego jednoznacznej definicji.

W znaczeniu medycznym "syndrom DDA" nie jest z założenia zespołem psychopatologicznym i z tego powodu nie jest uwzględniany (analogicznie do współuzależnienia) w żadnym systemie klasyfikacyjnym. Jednak biorąc pod uwagę między innymi cechy charakterystyczne, wspólne dla określonej populacji, badacze wprowadzają do literatury termin „syndrom dorosłego dziecka alkoholika".

Zofia Sobolewska-Mellibruda definiuje go jako

zespół utrwalonych osobowościowych schematów (poznawczych, emocjonalnych, behawioralnych i interpersonalnych) funkcjonowania psychospołecznego 
powstałych $\mathrm{w}$ dzieciństwie $\mathrm{w}$ rodzinie alkoholowej, które utrudniają osobie adekwatny, bezpośredni kontakt z teraźniejszością i powodują psychologiczne zamknięcie się $\mathrm{w}$ traumatycznej przeszłości. Powoduje to przeżywanie i interpretowanie aktualnych wydarzeń i relacji przez pryzmat bolesnych doświadczeń z dzieciństwa. Zniekształcenia te nie są przez osoby z syndromem DDA uświadamiane, a schematy są destrukcyjne i powodują wiele zaburzeń pacjenta w kontakcie z samym sobą oraz z innymi osobami, szczególnie z tymi, z którymi pacjent pozostaje w bliskich związkach (za: Jabłońska, Kucińska i Schirmer, 2008).

Odmienne objaśnienie terminu proponuje Agnieszka Litwa. Jej zdaniem syndrom DDA dotyczy osób,

u których siła zapisu traumatycznych wydarzeń życiowych w rodzinie z problemem uzależnień przekroczyła możliwości zaradcze ich systemu samoobrony, zostawiając trwałe ślady $\mathrm{w}$ obrazie siebie i funkcjonowaniu osoby, o cechach złożonego stresu pourazowego, nałożonego na różne konfiguracje cech osobowości. [...] Osoby takie przejawiają trudności w postaci: lęku przed bliskością, nieufności i wzmożonej kontroli, trudności w relacjach z ludźmi oraz problemy w kontakcie ze swoimi uczuciami i potrzebami (Litwa, 2009, s. 254).

Z kolei według Marzeny Kucińskiej (1999) syndrom DDA stanowi kompilację cech osobowości utrwalonych w okresie dzieciństwa, utrudniających adaptację w dorosłość i rozwój nowych cech. Cechy te łączą się ze strategiami kompensacyjnymi, które dziecko stosowało, aby przystosować się do warunków, w których przyszło mu dorastać. W dorosłym życiu problematyczne sytuacje mogą uaktywniać dziecięce strategie radzenia sobie ze stresem i blokować rozwój bardziej odpowiednich do aktualnych realiów postaw i reakcji (Kucińska, 1999).

Podsumowując, długotrwałe funkcjonowanie w specyficznych rolach psychologicznych wywiera ogromny wpływ na życie dorosłe osób pochodzących $z$ rodzin alkoholowych. Niejednokrotnie znane im z dzieciństwa schematy przenoszą $\mathrm{w}$ dorosłości na relacje międzyludzkie, małżeńskie, rodzicielskie i zawodowe. Mechanizm ten jest charakterystyczny dla wszystkich rodzin dysfunkcyjnych.

\section{Cechy charakterystyczne DDA}

Wychowanie w rodzinie dysfunkcyjnej sprzyja wykształceniu charakterystycznych cech osobowości oraz sposobów funkcjonowania społecznego. Zdaniem Janet Beigel Geringer Woititz (1992) DDA:

a) zgadują, jakie zachowania są normalne - ze względu na dorastanie w patologicznym środowisku rodzinnym, do którego musiały się przystosować, nie są w stanie rozpoznać, które zachowania i sytuacje wychodzą poza ramy społecznie akceptowane; 
b) mają trudności z przeprowadzeniem swoich zamiarów od początku do końca - w okresie dzieciństwa nie doświadczały akceptacji, wsparcia, motywacji czy też pochwały ze strony osób dorosłych, przez co nie są pewne realizacji swoich działań i celów. Charakteryzuje je zniechęcenie i przesadne oczekiwania wobec efektów własnej pracy;

c) kłamią nawet wtedy, gdy równie dobrze mogłyby powiedzieć prawdę - kłamstwo w rodzinie alkoholowej zajmowało bardzo wysoką pozycję, pozwalając na codzienne przetrwanie. Najczęstsze formy kłamstwa, które wyniosły z domu, to: zaprzeczanie, usprawiedliwianie się, ukrywanie problemu;

d) bezlitośnie siebie osądzają - w ich systemie rodzinnym były nieustannie krytykowane, niejednokrotnie słysząc, że są przyczyną wszelkich kłopotów, w związku z czym są przepełnione negatywnymi uczuciami wobec siebie: nie cieszą się z sukcesów, bagatelizują je, obwiniają się za wszelkie niepowodzenia;

e) traktują siebie bardzo poważnie oraz trudno im się bawić i cieszyć - w dzieciństwie doświadczały zazwyczaj negatywnych uczuć, takich jak: smutek, złość, wstyd, strach itd. Przez brak lub nieliczne momenty radości w życiu dorosłym są bardzo poważne, często przygnębione i nie potrafią odpoczywać;

f) mają trudności w nawiązywaniu bliskich kontaktów - z uwagi na brak pozytywnych i zdrowych wzorców budowania bliskich relacji z drugą osobą $\mathrm{w}$ domu rodzinnym odczuwają silny lęk przed porzuceniem, łatwo uzależniają się emocjonalnie, a krytyka powoduje u nich poczucie beznadziei;

g) przesadnie reagują na wszelkie zmiany, będące poza sferą ich oddziaływania - dorastanie w rodzinie alkoholowej nauczyło je, że mogą liczyć tylko na siebie oraz że nie mają wpływu na sytuację w domu rodzinnym. $Z$ tego powodu, będąc dorosłymi, także polegają tylko na sobie i chcą wszystko kontrolować, wychodząc z przeświadczenia, że dzięki temu unikną zranień i problemów. Wszystkie nagłe i niekontrolowane zmiany powodują u nich lęk, stąd ciężko jest im znaleźć lepszą pracę czy też rozstać się z osobą, z którą nie chcą już być;

h) nieustannie poszukują potwierdzenia i uznania - negatywny obraz własnej osoby, który wykreował się w okresie dzieciństwa, w dorosłym życiu usiłują naprawić, stając się perfekcjonistami, pomagając potrzebującym czy też poświęcając się dla innych, jednak w zamian za to oczekują wdzięczności i gestów przyjaźni, miłości; 
i) myślą, że różnią się od wszystkich - wychodzą z założenia, że nikt ich nie zaakceptuje, gdyż na akceptację muszą sobie zapracować i zasłużyć. Regularnie doświadczają uczucia wstydu przed rówieśnikami, a także w okolicy zamieszkania, wychodząc z założenia, że nie są lubiane ze względu na swoją dziwność, odmienność;

j) bywają nadmiernie odpowiedzialne albo nadmiernie nieodpowiedzialne - stanowi to konsekwencję przyjmowanej w dzieciństwie roli (np. „bohater rodziny” lub „błazen”);

k) są niezwykle lojalne, nawet w obliczu dowodów, że druga strona na to nie zasługuje - strategia ta wynika z doświadczeń z dzieciństwa, gdzie cała rodzina dążyła do bycia razem i niesienia pomocy rodzicowi alkoholikowi. Niejednokrotnie wierzą, że ich sytuacja nie może ulec poprawie, stąd w życiu dorosłym są uwikłane w związki, będące dla nich powodem cierpienia, jednak nie mają odwagi, aby je przerwać. Nie spodziewają się, że mogą stworzyć związek, który dałby im więcej niż to, czego doznały w domu rodzinnym;

1) łatwo ulegają impulsom - będąc dzieckiem nie mogły przejawiać zachowań impulsywnych, tak jak inne dzieci, gdyż przebywanie w rodzinie z problemem alkoholowym zobowiązywało je do pełnienia ról, które przynależą osobom dorosłym. Z tego powodu w dorosłości wypełniają ten deficyt (por. Woititz, 1992, s. 29-60).

Ponadto DDA charakteryzuje zaniżona samoocena. Przekonanie o swojej niższej wartości prowadzi do tego, że DDA przez całe życie wstydzi się siebie. Badacze wskazują na dwie strategie radzenia sobie przez nie z poczuciem niedowartościowania - poprzez zachowania perfekcyjne, czyli stawianie sobie bardzo wysokich wymagań w celu potwierdzenia samooceny, oraz zachowania unikowe, czyli rezygnowanie z trudnych zadań, by nie wystawić się na ryzyko porażki (Woititz, 1992). Dorota Dyjakon wyróżnia jeszcze dwa mechanizmy, które są obecne w życiu dorosłych dzieci alkoholików. Są to: amnezja dyssocjalna - czyli całkowite wypieranie całych zdarzeń (z reguły bardzo bolesnych, takich jak molestowanie bądź przemoc), które wydarzyły się w dzieciństwie, oraz poszukiwanie defektu, samoobwinianie - opierające się na obarczaniu siebie winą za poczucie braku szczęścia, wycofanie bądź nadpobudliwość (Dyjakon, 2012). Natomiast John Bradshaw wymienia dodatkowo nałogowe, kompulsywne zachowania lub małżeństwo z osobą uzależnioną. Owa cecha odnosi się nie tylko do problemu wchodzenia w związki ze sobą osób, które dorastały w rodzinie $\mathrm{z}$ problemem alkoholowym, ale także ich uzależnienia. DDA są w większym stopniu niż inne osoby skore do 
ucieczki od problemów w alkohol, inne środki psychoaktywne, pracę, seks czy też hazard (Bradshaw, 1994).

W przytoczonym powyżej zestawieniu można dostrzec obraz współczesnego nastolatka lub młodej osoby dorosłej, przewrażliwionych na punkcie własnego wizerunku, nieustannie poszukujących potwierdzenia i uznania na licznych społecznościowych forach. To oni w realnym świecie mają problem w nawiązywaniu bliskich relacji, bawią się "na siłę" wewnątrz doświadczając głębokiego smutku, nie wiedzą, co jest normalne, działają impulsywnie i unikają odpowiedzialności. Myślą, że różnią się od wszystkich, mają problemy z samooceną i uciekają w zachowania kompulsywne.

\section{Strategie życiowe DDA}

Z doświadczeń pracy klinicznej wynika, że coraz większa ilość osób z rodzin alkoholowych ma świadomość swoich deficytów w funkcjonowaniu psychospołecznym. Badania funkcjonowania psychospołecznego DDA prowadzone w Instytucie Psychologii Zdrowia Polskiego Towarzystwa Psychologicznego pokazują, że osoby te charakteryzuje wyższy wskaźnik depresji, lęku i nadwrażliwości interpersonalnej aniżeli osoby dorastające w rodzinach bez problemu alkoholowego. Ponadto cechuje je również zauważalnie niższe poczucie sensu życia, zaradności życiowej i gorsze rozumienie siebie i innych (Filipiak, 2007).

Zważywszy na różne strategie funkcjonowania w życiu społecznym, Elwyn James Anthony wyróżnia trzy kategorie DDA:

a) żelazne dzieci - czyli osoby, które odczuwają nieprzerwanie potrzebę kontrolowania sfery fizycznej, emocjonalnej i społecznej swojego życia, Jednakże posiadają one pewne zasoby i zdolności, dzięki którym sprawiają wrażenie znajdowania się w lepszej pozycji niż inne DDA. Przekłada się to na szereg umiejętności:

- uzyskiwania wsparcia i korzystania z niego,

- kierowania otoczeniem oraz poczucia własnej siły (skłonność do pomocy innym),

- osiągnięcia możliwie wczesnej autonomii względem swojej rodziny (odizolowują się od swojej rodziny, nie zrywając z nią kontaktu, a koncentrując się na więzach z innymi grupami, takimi jak wspólnoty, harcerstwo),

- łatwego zawierania nowych znajomości i odnoszenia się do innych osób $\mathrm{w}$ taki sposób, aby czuły się w ich towarzystwie dobrze (pomaga im to w ustrzeżeniu się przed izolacją społeczną i samotnością),

- akceptowania i oswajania trudnych uczuć,

- konstruktywnego radzenia sobie ze stresem, 
- poszukiwania sensu życia i wytyczania coraz nowszych celów życiowych;

b) plastikowe dzieci - czyli grupa osób, która nie była w stanie sprostać codziennym trudnościom doświadczanym w okresie dzieciństwa i z tego względu w dorosłym życiu wciąż towarzyszy im ciężar doznanych urazów. Tkwią we współuzależnieniu na tyle głęboko, że nie potrafią opuścić swojego domu rodzinnego zarówno w sensie fizycznym, jak również emocjonalnym. Wyzbywają się własnych potrzeb, marzeń i pragnień na rzecz problemów występujących w rodzinie alkoholowej. Kluczowe problemy, z jakimi mają do czynienia DDA w tej grupie, dotyczą sfery emocjonalnej i poznawczej;

c) szklane dzieci - czyli grupa osób, w której charakteryzowaniu można użyć metafory rozbitej szklanki, na której nawet po bardzo precyzyjnym sklejeniu zostają rysy. Osoby te zmagają się z depresją i zaburzeniami osobowości, które przejawiają się w łamaniu prawa, nieadekwatnym funkcjonowaniu w życiu społecznym i zawodowym oraz byciu prowodyrem rodzinnych konfliktów. Ich życie determinuje lęk o życie swoje i najbliższych (za: Gąsior, 2010).

Różne rodzaje osobowości reprezentowane przez Dorosłe Dzieci Alkoholików wiążą się ze strategiami radzenia sobie z przeszłością, które przyjmują w dorosłym życiu. Joanna Wawerska-Kus wymienia następujące strategie: rodziny zastępczej, Zosi Samosi, bólów fantomowych, protezy oraz afirmacji braku (Wawerska-Kus, 2009).

Pierwszym ze sposobów radzenia sobie z przykrymi doświadczeniami z dzieciństwa i niezaspokojonymi w tym okresie potrzebami jest głęboko zakorzenione przekonanie, że braki można wypełnić relacjami z innymi ludźmi. DDA sądzą, że inni ludzie są w stanie zastąpić im rodziców oraz że to, czego nie otrzymali w dzieciństwie jest do nadrobienia. Potencjalnymi osobami, które w przeświadczeniu DDA zaspokoją ich potrzeby są „przyszywani rodzice”. Mogą być nimi: współmałżonek, teściowie, przyjaciele, a niekiedy własne dzieci. Stosowanie tej strategii jest przyczyną blokowania własnych emocji, unikania tego, co niemiłe, czyli złości, bólu, żalu czy strachu. Separowanie nieprzyjemnych uczuć pociąga za sobą w tym wypadku również tłumienie emocji pozytywnych. Inną odmianą tej strategii jest „zassanie”, czyli emocjonalne zespolenie $\mathrm{z}$ drugą osobą, czego wynikiem jest między innymi współuzależnienie.

W przypadku strategii Zosi Samosi znamienne jest przeświadczenie, że można polegać wyłącznie na sobie. Nie ma tu miejsca dla chwili słabości, 
bezradności czy smutku. Przeciwnie - u podstaw tej strategii leży zaprzeczanie własnemu wizerunkowi jako osoby bezradnej i niewystarczająco silnej. Pierwsza taka negacja łączy się z zaspokojeniem potrzeb. Typ Zosia Samosia utrzymuje, że nie miał potrzeb, np.: „Ja nigdy nie lubiłam być przytulana”. Kolejno następuje zanegowanie jakiejkolwiek doznanej krzywdy, gdyż uznanie faktu jej doświadczenia oznaczałoby poświadczenie własnej słabości. Osoby te wyróżnia ponadprzeciętna empatia, która przyczynia się do wyboru zawodu opierającego się na pomocy innym.

Ból fantomowy jest swego rodzaju iluzją dotyczącą amputowanej kończyny. Osoba po amputacji, pomimo świadomości jej braku, odczuwa w niej ból, swędzenie czy drętwienie. U DDA taka iluzja odnosi się do własnego dzieciństwa, które uważają za udane, a przyczyn wszelkich niepowodzeń szukają w sobie. Osoby te niejednokrotnie mają problemy z interpretowaniem niewerbalnych przekazów i ignorują instynkt samozachowawczy. DDA wykorzystujące strategię bólów fantomowych usiłują również domyślać się, czego się od nich oczekuje oraz wyolbrzymiają swoje niepowodzenia.

W strategii protezy charakterystyczne jest wpisanie własnej krzywdy i niezaspokojenie potrzeb w porządek świata. Oznacza to, że osoby przyjmujące tę konwencję nie zaprzeczają wydarzeniom $z$ dzieciństwa, nie biorą także na siebie za nie winy, jednak równocześnie żyją w przeświadczeniu, że rodzice również nie są winni. W zasadzie nie obwiniają nikogo, uważając, że tak „po prostu wyszło”. Ból zostaje przesunięty do sfery tabu, podobnie jak krzywda. Natomiast w głębi duszy dochodzi do przekonania o byciu osobą nic niewartą, niezasługującą na miłość. Takie DDA uważają, że zasłużyły na to, co je spotkało. Jednak różnica pomiędzy protezą a bólem fantomowym polega na tym, że w tym pierwszym przypadku chodzi raczej o sferę tożsamości (czyli nie „zrobiłem coś złego”, a „jestem zły”).

Ostatnia strategia - afirmacji braku - opiera się na postrzeganiu świata poprzez pryzmat swoich krzywd i niezaspokojonych potrzeb. Osoby ją stosujące niejako afirmują swoje niezaspokojone potrzeby z dzieciństwa, oczekując bezwarunkowej akceptacji tego stanu rzeczy i wsparcia w swoim cierpieniu. Odczuwają poczucie braku zrozumienia przez otoczenie i nieustannie poszukują potwierdzenia swojej wizji siebie i świata. Wiele z tych osób ma skłonności do uzależniania się. Niektóre z nich wykazują również tendencje do stosowania przemocy wobec bliskich. Tłumaczą ten fakt nawykiem wyniesionym $\mathrm{z}$ domu. Łączy się to zwłaszcza $\mathrm{z}$ unikaniem odpowiedzialności za siebie i ponoszenia konsekwencji własnych działań (Wawerska-Kus, 2009). 


\section{Formy pomocy dla DDA}

Pierwszym krokiem do przemiany jest uświadomienie sobie, kim się jest i jaki wpływ na obecne życie wywarła sytuacja rodzinna związana z uzależnieniem od alkoholu rodzica. Szereg DDA przez długie lata zmaga się np. z depresją bądź lękami, sądząc, że to z nimi jest „coś nie tak”. Nie dopuszczają myśli, że obecny stan rzeczy jest konsekwencją dorastania w rodzinie alkoholowej. Dopóki nie nastąpi uświadomienie tego faktu, dopóty nie będzie możliwa zmiana (Kucińska, 2003, s. 43).

Pierwsze, podejmowane przez DDA, zorganizowane próby przekraczania destrukcyjnych uwarunkowań wyniesionych $\mathrm{z}$ domu rodzinnego odbywały się $\mathrm{w}$ ramach działań samopomocowych rodzin związanych ze wspólnotą Anonimowych Alkoholików. Wspólnota powstała w latach 30. XX wieku w Stanach Zjednoczonych, a już na przełomie lat 50. i 6o. funkcjonowały w niej grupy samopomocowe pracujące wg programu „12 Kroków” DDA. Jest to program odnowy moralnej i rozwoju duchowego czerpiący z tradycji chrześcijańskiej, jednak dzięki odwołaniu do ponadreligijnej idei „mocy większej od nas samych" doskonale funkcjonujący w środowisku osób należących do różnych wyznań, a także niewierzących. Ich zdaniem receptą na poczucie braku kontroli nad własnym życiem jest zwrot ku duchowości i powierzenie się opiece Boga, „jakkolwiek Go pojmujemy”. „12 Kroków” to dla wielu ludzi wyznacznik zasad postępowania i sposób na zaprowadzenie porządku w swoim życiu, w którym zabrakło konstruktywnych norm wyniesionych $\mathrm{z}$ domu rodzinnego.

\section{Kroków DDA}

1. Przyznajemy, że jesteśmy bezsilni wobec naszego uzależnienia i naszych problemów - i że nie możemy już dać sobie rady z naszym życiem.

2. Uwierzyliśmy, że moc większa od nas samych może przywrócić nam duchowe zdrowie.

3. Postanowiliśmy powierzyć naszą wolę i nasze życie opiece Boga, na ile Go pojmujemy.

4. Zrobiliśmy radykalny i odważny obrachunek moralny w głębi duszy.

5. Bez ukrywania wyznaliśmy Bogu, sobie i drugiemu człowiekowi istotę naszych błędów.

6. Staliśmy się całkowicie gotowi, aby Bóg uwolnił nas od wszystkich wad charakteru.

7. Zwróciliśmy się do Niego w pokorze, aby usunął nasze braki.

8. Zrobiliśmy listę osób, które skrzywdziliśmy i staliśmy się gotowi zadośćuczynić im wszystkim. 
9. Zadośćuczyniliśmy osobiście wszystkim, wobec których było to możliwe, z wyjątkiem tych przypadków, gdy zraniłoby to ich lub innych.

10. Prowadziliśmy nadal obrachunek moralny, z miejsca przyznając się do popełnianych błędów.

11. Dążyliśmy poprzez modlitwę i medytację do coraz doskonalszej więzi z Bogiem, na ile Go pojmujemy, prosząc jedynie o poznanie Jego woli wobec nas oraz o siłę do jej spełnienia.

12. Przebudzeni duchowo, w rezultacie tych „Kroków”, staraliśmy się nieść posłanie innym ludziom i stosować te zasady we wszystkich naszych poczynaniach (za: Jaworski, 2004, s. 16).

Program ten pozwala uporządkować sferę moralną i czerpać siłę $\mathrm{z}$ relacji z Absolutem, a także uczestnictwa we wspólnocie. Mimo rosnącej liczby ofert terapii adresowanej do osób wychowanych $\mathrm{w}$ rodzinach dysfunkcyjnych, grupy samopomocowe DDA nadal stanowią najbardziej popularną formę wsparcia.

Typową formą profesjonalnej terapii DDA są programy uczące brania odpowiedzialności za własne życie oraz korygujące destrukcyjne schematy zachowań stosowane $\mathrm{w}$ przeszłości. Terapia grupowa jest wspomagana książkami, ćwiczeniami, technikami medytacyjnymi, kwestionariuszami autodiagnostycznymi oraz innymi materiałami obejmującymi teoretyczne i praktyczne wytyczne dla DDA (Woydyłło, 2009).

Równie często osoby wychowane w rodzinach $\mathrm{z}$ problemem alkoholowym korzystają z terapii indywidualnej. Jak zwraca uwagę Marzena Kucińska, $\mathrm{w}$ terapii odbywającej się podczas sesji terapeutyczno-rozwojowych dla DDA można wydzielić trzy fazy. W pierwszej fazie uświadamia się DDA, jak funkcjonuje rodzina alkoholowa, co spotyka dzieci, które się w niej wychowują, i jaki wpływ doświadczenia z dzieciństwa wywierają na dorosłe życie. Każda z osób ma możliwość indywidualnego przeanalizowania swojej własnej sytuacji i wywnioskowania, które z obecnych problemów mają źródło w wydarzeniach z przeszłości. Badaczka stwierdza, że okres ten można by określić mianem fazy edukacyjno-diagnostycznej, gdyby nie fakt, że już w tym momencie szybko postępuje proces terapeutyczny. Otrzymana wiedza, odniesiona do własnej osoby, umożliwia zrozumienie i usystematyzowanie dotychczasowych doświadczeń i powoduje chęć dzielenia się nimi, i rozbudza tłumione dotychczas uczucia (Kucińska, 2002).

Kolejnym etapem jest wnikliwa praca psychoterapeutyczna. Jej problematyka jest uwarunkowana indywidualnymi potrzebami, lecz zazwyczaj dotyczy spraw związanych z rozrachunkiem z przeszłością. Dają o sobie znać doznane krzywdy oraz niezaspokojone potrzeby, widma ważnych osób, a pacjenci usiłują rozprawić się z nimi z perspektywy osoby dorosłej (Kucińska, 2002). 
Ostatnią fazą jest porządkowanie aktualnego życia. Osoby uczestniczące $\mathrm{w}$ terapii na tym etapie analizują różne sfery własnego funkcjonowania pod względem zadowolenia $\mathrm{z}$ nich. W następnej kolejności tworzą własny plan uwzględniający rozwój obszarów, z których są zadowolone, oraz zmiany tych, które wymagają korekty. Wiele z dorosłych dzieci alkoholików zaczyna wprowadzanie zmian w swoim życiu od odpowiedzi na pytania: kim jestem, kim chciałbym być i jakie są $\mathrm{w}$ moim życiu priorytety (Kucińska, 2002). Najważniejszymi zagadnieniami $\mathrm{w}$ procesie zdrowienia DDA są zdaniem badaczy: umiejętność wyznaczania granic, wyrażania własnego zdania oraz porzucenia wcześniej pełnionych ról.

Zarówno terapia indywidualna, jak i grupowa stanowią formy pomocy dorosłym dzieciom alkoholików, mieszczące się $\mathrm{w}$ ramach oddziaływań wskazanych przez Państwową Agencję Rozwiązywania Problemów Alkoholowych. Dla podgrupy z syndromem DDA są to:

a) interwencja i poradnictwo ukierunkowane na motywowanie do rozpoczęcia psychoterapii (pomoc o charakterze krótkotrwałym);

b) psychoterapia (krótko- i średnioterminowa) (Jabłońska, Kucińska i Schirmer, 2008).

Podsumowując, obecnie coraz większą uwagę zwraca się na konsekwencje dorastania w rodzinie alkoholowej, widoczne w dorosłym życiu. Tworzy się coraz więcej grup samopomocowych DDA oraz powstaje wiele nieoficjalnych stron internetowych o tematyce DDA, które często są pierwszym krokiem do uświadomienia sobie występowania objawów tego syndromu we własnej osobowości. Połączenie oddziaływań o charakterze terapeutycznym i praca nad własnym rozwojem duchowym w ramach wspólnoty DDA daje możliwość diagnozy przyczyn doświadczanych problemów, korekty dysfunkcyjnych schematów przekonań i zachowań oraz zbudowania fundamentu rozwoju osobowego poprzez wzięcie świadomej odpowiedzialności za własne życie i wybory moralne.

\section{Nie tylko alkohol}

Na zakończenie chciałabym raz jeszcze zwrócić uwagę na fakt, że problemom DDA poświęcono wiele miejsca w literaturze naukowej i publikacjach popularyzujących wiedzę $\mathrm{z}$ tego zakresu, tymczasem specyficzne zmiany w osobowości i trudności w obszarze funkcjonowania społecznego dotyczą ogromnej liczby osób, które wychowały się lub wychowują w rodzinach obarczonych dysfunkcjami innego rodzaju (Kowolik, 2017). Zmiany społeczne, 
ekonomiczne i cywilizacyjne pociągają za sobą nieuchronnie przeobrażenia w strukturze i funkcjonowaniu rodziny. Przeobrażenia te widoczne są nie tylko w liczebnym ograniczeniu członków rodziny (przejście od rodzin wielopokoleniowych i wielodzietnych do rodziny nuklearnej), w zasadzie zamieszkiwania małżeństw (przejście od patrylokalności i matrylokalności do coraz większej neolokalności), czy też $\mathrm{w}$ posługiwaniu się autorytetem (przejście od tradycyjnego patriarchatu do nowoczesnego egalitaryzmu), jak również w pojawiających się alternatywnych formach życia małżeńsko-rodzinnego (niezamężna kohabitacja, życie w samotności, monoparentalność). Zmienia się rola kobiety i mężczyzny w rodzinie, ich funkcje ekonomiczne, liczba zawieranych małżeństw i liczba rozwodów. Transformacje społeczne i kulturowe (rozpowszechnienie się wiedzy psychologicznej i medycznej, oddzielenie religii od życia społecznego) oraz przemiany wartości (wzrost znaczenia wartości związanych z wolnością jednostki i samorealizacją) skutkują odwróceniem się od rodziny i skupieniem uwagi przede wszystkim na sobie. Proces indywidualizacji dostrzegalny jest we wszystkich wymiarach życia społecznego, nadrzędnymi wartościami stają się samorealizacja i wolność jednostki, czyli swoboda stanowienia o samym sobie, możliwość dokonywania nieustannych wyborów pomiędzy tym, co zabronione i dozwolone, pomiędzy tym, co wolno a czego nie wypada robić. Taka sytuacja burzy dotychczasowy porządek, wprowadzając dużą dozę niestabilności i możliwość występowania wielu konfliktów oraz niepożądanych zjawisk wewnątrz samej rodziny. Konsekwencje tych przeobrażeń dotykają przede wszystkim dzieci (Dębski, 2011). Trudno porównywać skalę problemów adaptacyjnych dzieci wychowywanych w rodzinach alkoholowych i tych doświadczających innego rodzaju dysfunkcji. Niewątpliwie wspólnym mianownikiem jest tutaj brak poczucia bezpieczeństwa i stabilności, niejasność norm i zasad, brak pozytywnych wzorców osobowych, co bardzo utrudnia, a niekiedy uniemożliwia wykształcenie zdrowej tożsamości, adekwatnego poczucia własnej wartości oraz nabycie zdolności do tworzenia trwałych i harmonijnych związków z innymi ludźmi. Warto przyjrzeć się z tej perspektywy drodze, którą wytyczyły dorosłe dzieci alkoholików i skorzystać $\mathrm{z}$ ich doświadczeń w przekraczaniu destrukcyjnych uwarunkowań wyniesionych $\mathrm{z}$ domu rodzinnego.

\section{BIBLIOGRAFIA}

ARC Rynek i Opinia. (2017). Raport: 25 trendów konsumenckich. Pozyskano z: https://arc.com.pl/ Raport-25-trendow-konsumenckich-blog-pol-1534965225.html, [data dostępu: 19.02.2020]. Badora, K.P., Badora, S. (1999). Dysfunkcje i zjawiska patologiczne we współczesnych rodzinach. Pozyskano z: http://bazhum.muzhp.pl/media//files/Prace_Naukowe_Pedagogika-r1999_ 2000_2001-t8_9_10-S437-449/pdf, [data dostępu: 14.01.2019]. 
Biernat, R. (2015). Zachowania dewiacyjne młodzieży w kontekście dysfunkcji i patologii życia rodzinnego. Pozyskano z: cejsh.imc.edu.pl, [data dostępu: 17.02.2020].

Bradshaw, J. (1994). Zrozumieć rodzinę. Rewolucyjna droga odnalezienia samego siebie. Przeł. H. Szczepańska. Warszawa: Instytut Psychologii Zdrowia i Trzeźwości PTP.

Dąbrowska, A. (2018). Dorosłe dzieci z rodzin dysfunkcyjnych, czyli kilka słów o funkcjonowaniu oraz konsekwencjach życia w nieprawidłowym środowisku wychowawczym. Problemy Opiekuńczo-Wychowawcze, t. 58, 3 (568), 3-15.

Dębski, M. (2011). Krzywdzenie dziecka w rodzinie. Społeczne uwarunkowania i próby rozwiq̨zań na podstawie gdyńskich działań profilaktycznych. Gdynia: MERITUM.

Dyjakon D. (2012). Świat według DDA. Świat Problemów, 2, 16-19.

Filipiak, M. (2007). Świat dorosłych dzieci alkoholików. Przegląd Terapeutyczny, 2.

Gąsior, K. (2010). Dorośli, dzieci alkoholików: kim są i czy potrzebują terapii? Świat Problemów, 6, 5-8.

Jabłońska, D., Kucińska, M., Schirmer-Rychlicka, G. i in., Standardy form pomocy psychologicznej dla różnych grup dorosłych dzieci alkoholików oraz kwalifikacji. Pozyskano z: http:// www.parpa.pl/index.php/rodzina-dzieci/standardy-form-pomocy-psychologicznej-dlaroznych-grup-doroslych-dzieci-alkoholikow, [data dostępu: 07.01.2019].

Jaworski, R. (2004). Wreszcie żyć - 12 kroków ku petni życia. Płock: Wydawnictwo CAMEL.

Klinger, K., Otto, P. (2019). Czarne statystyki. Coraz więcej prób samobójczych. Pozyskano z: https://serwisy.gazetaprawna.pl/edukacja/artykuly/1414773,samobojstwa-w-szkole-mlodziez-nie-chce-zyc.html, [data dostępu: 19.02.2020].

Kowolik, P. (2017). Zjawiska patologii we współczesnych rodzinach polskich. Nauczyciel i Szkoła, 1 (61), 59-76.

Kucińska, M. Terapia dorosłych dzieci alkoholików (DDA). Pozyskano z: http://www.psychologia.edu.pl/czytelnia/5o-artykuly/1022-terapia-doroslych-dzieci-alkoholikow-dda.html, [data dostępu: 17.01.2019].

Kucińska, M. (1999). Alkoholowy dom i życie z alkoholikiem. Świat Problemów, 10 (81), 32-34.

Kucińska, M. (2003). DDA, czyli Dorosłe Dzieci Alkoholików. W: P. Żak (red.), Gdzie się podziało moje dzieciństwo. Kielce: Wydawnictwo Charaktery.

Litwa, A. (2009). Syndrom DDA. W: B. Bętkowska-Korpała (red.), Uzależnienia w praktyce klinicznej. Zagadnienia diagnostyczne. Warszawa: PARPA.

NIK. (2017). NIK o pomocy psychologiczno-pedagogicznej dla uczniów. Pozyskano z: https:// www.nik.gov.pl/aktualnosci/nik-o-pomocy-psychologiczno-pedagogicznej-dla-uczniow. html, [data dostępu: 19.02.2020].

Ryś, M. (2007). Rodzinne uwarunkowania psychospołeczne funkcjonowania Dorostych Dzieci Alkoholików. Warszawa: PWN.

Ślaski, S. (2005). Dorosłe dzieci alkoholików oraz ich rodzice - aktualny stan badań. Roczniki Psychologiczne, t. 8, 2, 37-54.

Wawerska-Kus, J. (2009). Dzieciństwo bez dzieciństwa. Warszawa: Dywiz.

Winiarski, M. (200o). Rodzina - szkoła - środowisko lokalne. Problemy edukacji środowiskowej. Warszawa: Instytut Badań Edukacyjnych.

Woititz, J.G. (1992). Dorosłe dzieci alkoholików. Warszawa: Instytut Psychologii Zdrowia i Trzeźwości PTP.

Woydyłł, E. (2009). Poprawka z matury. Kraków: Wydawnictwo Literackie. 


\section{SUMMARY}

\section{Overcoming destructive patterns of family environment by Adult Children of Alcoholics}

In times of family crisis, the author indicates the similarities between an alcoholic family and a family in crisis caused by contemporary social changes. The experience of being raised in a family with alcohol problem can provoke specific changes in the structure of personality and emotional dysfunctions referred to as Adult Children of Alcoholics (ACOA) Syndrome. This paper presents a description of ACOA and life strategies they adopt. According to the author, various forms of ACOA support can be useful in therapy and in the process of self-development of people brought up in dysfunctional families.

KEYWORDS: dysfunctional family, adult children of alcoholics, life strategies, spiritual development, therapy 